\title{
Explaining the relationship between changes in Iranian lifestyle and metamorphosis of urban form of residential environment in contemporary Iran. Case study: Mashhad
}

\author{
Ali Abedzadeh', Abdolhadi Daneshpour ${ }^{2}$, Maryam Ostadi ${ }^{1}$ \\ ${ }^{1}$ Department of Urban Planning and Design, Mashhad Branch, \\ Islamic Azad University, Mashhad, Iran \\ ${ }^{2}$ School of Architecture and Environmental Design, \\ Iran University of Science \& Technology, Tehran, Iran \\ E-mail: ali.abedzadeh@yahoo.com, daneshpour@iust.ac.ir, \\ ostadimr@gmail.com
}

\begin{abstract}
Humanity settlement are formed as a result of decisions and actions of different people and become as a form of an identity of integrity. So urban form is influenced by desires, values, beliefs, and human activities, so the study of urban form is the study of its constituent human values and expression of physical aspects of their lifestyles. Before contemporary periods, urban form in Iran, continuity based on former patterns of changes, which was gradual, but after the beginning of the influence of west, one of the most important challenges of urban form in Iran is in the form of short-term changes. Changes occur in a cycle of destruction and construction. This paper use the way of content analysis investigate to texts, document to study form and typo-morphology of residential environment in the city of Mashhad. In the periods of one hundred years shows there is a direct and significant relationship between changes of Iranian lifestyle and metamorphosis of urban form, so that by sequential developments of Iranian lifestyle in a short time, the urban form is responded and metamorphosed and again is created in a new form.
\end{abstract}

Keywords: Urban form, metamorphosis, lifestyle, residential environment, Iran

\section{Introduction}

Humanity settlement design deals with the selection of a solution amongst all possible solutions. The selection usually matches with the culture of its inhabitants and makes locations discrete from each other. These sustainable choices usually establish a particular style in life or environment (Rapoport quoted to Catanese, Snyder,1979). Therefore, the physical aspect of urban areas is the impact and effect of human intensions and activities and the study of urban structure is the study of the human values that shaped it. In other words, the urban tissue is not only the historical document of its construction; but, it is also the document to the life style of those who made it and lived in there, Moudon believes that although morphology focuses on the study of city as a physical environment, it implicitly establishes a link between spatial and phisical elements of city, and the social and economic forces which shaped the city (Moudon, 2000). In other words, houses and humanity settlements are the materialistic explanation of life style, i.e. life style establishes symbolic essence of them (Rapoport, 1969). On this basis, the main purpose of housing deals with the establishment of a compatible environment, consistent with human lifestyle (Pourdeihimi, 
2011). Therefore, this paper tends to investigate the evolution of typomorphology of residential environments in the city of Mashhad, on the one hand and on the other hand it investigate the changes in Iranian lifestyles in the contemporary era, and to determine and explain the relationship of changes in Iranian lifestyles with the metamorphosis of the urban form of residential environments in contemporary Iran.

\section{Methodology}

This paper applies qualitative method. Documentary study was used for data collection. Typo-morphology was applied to recognize and analyze urban for of residential environments. At last, content analysis method was codified to analyze the interrelation of changes in Iranian life style with the metamorphosis of the urban form of residential environments in contemporary Iran.

\section{Measurement and analysis}

In this section, the changes in contemporary Iranian lifestyle are analyzed; analyzing the changes in residential tissues in Iran, it then investigates typo-morphology evolutions of residential environments in Mashhad:

Changes in Iranian lifestyle in contemporary era:

Lifestyle is consists of two words: "life" and "style". The word "lifestyle" in the dictionary meaning of which is a combination of individual and group life or culture (Webster Dictionary, 2004) and it is defined as a particular way of life of a person or group (Oxford Dictionary, 1990). It is more than a hundred years that the concept of life style has been emerged (Veblen 1899, Weber 1922 and Simmel 1904); but in recent decades and especially with the emergence of consumerism in societies, this concept has got new definitions and it has given a much of the social sciences. Various scholars in the social sciences have presented different definitions of lifestyle. Studies show that these definitions are in a wide range; on one end of which is Alfred Adler who defines the lifestyle on individual basis and defines it based on psychology; on the other hand of which is Max Weber who defines lifestyle based on sociology and the concept of social stratification. In the middle of the aforesaid ranges, there are some scholars such as Simmel, Bourdieu and Giddens who search the lifestyle in both individual and collective aspects. Analysing the evolution of lifestyle concept reveals that lifestyle in traditional (pre-industrial) societies was unity-oriented and based on social integration (Benedikter, 2011). In these communities, the basis for the social identity of an individual dealt with his assigned characteristics (Abazari, Chavoshian, 2002) and the social was not separated from the political, economic and the culture and the focus was on political issues (Azadarmaki quoted from Hajiani, 2007). In modern industrial society, productive activity and the role individuals in production system are the foundations of social identity of individuals, which led to the emergence of the social class concept in this period (Abazari, Chavoshian, 2002).

In this period, the economy got importance, because modernity bears more economic nature, in comparison with political, social and cultural aspects (Azadramaki quoted to Hajian, 2007). But in recent decades by changing in the role of individuals in production system, to their role in the consumption system and the emergence of individual consumption behavior, a new concept of lifestyle has emerged (Abazari, Chavoshian, 2002); the social and cultural affairs got importance and the middle class was established; it is not retractable like pre-modernistic society (Azadramaki quoted to Hajian, 2007); thus, it led in forming a diverse and pluralistic societies. This interprets that a society with less diversity and less development has less distinct and independent lifestyles; where higher public acceptance of lifestyle, the community becomes more free, more democratic and more open (Benedikter, 2011).

In order to understand the changes in contemporary lifestyles of Iranians, we should consider its historical tissue. Before the modern era, Iranians has been having eventful historical environment of insecurity, instability, and chaos as much as it provided the field of 
authoritarianism. In this way, people selected how two live to remain (Farasatkhah, 2016). Piran knows the key to understand the rich history of Iran in the dialectic of construction and destruction, and also, centralization and decentralization; he believes that the Iranians in the historical past obeyed authority and violation of individual rights in the light of security (Piran, 2005). It appeared that the dialectic between construction and destruction turned the historical periods of the short-term Iranian society subject to the theory of shortterm society. Katozian applied the words "Old House" to show the short-term Iranian society. Most of old houses have not more than twenty or thirty years in age; they often have proper structures and they may be renewed using measures of conservation; but the reason which leads to their conviction and finally makes the building worthless and attends to the value of land is the architecture of the buildings which is not according to the latest fashion and friendly style. So instead of modernizing and increasing the available capital, the entire building is destroyed and other building stands instead of which (Katozian, 2014).

The basic contents of lifestyle in Iran may be searched and traced in the emergency of the middle class. Over the last century, Middle class designed the foundations of changes and also acted as the change agent (Azadramaki quoted to Hajian, 2007); the role of this class in two main events of the contemporary history of Iran was notable: one, the constitutional movement at the beginning of the century and the second one, was the Islamic revolution in 1978; despite all the political perceptions, both revolutionary movements reflected the national efforts to embrace modernity (Mirsepassi, 2014). Azadramaki regards the Iranian lifestyle as a way of expressing social and cultural distinctions affected by the four elements consisting the middle class, generation, gender and urbanization. These four intervened elements result in attendance of new forces in consumption market and it affects the social life of Iranians in transaction. He emphasized on the plurality, silence (resulted from the suppression of the middle class in contemporary Iranian history) and the influence of family and religion (A hidden life form in family and religion) as lifestyle characteristics of Iranian life style (Azadramaki quoted from Hajian, 2007).

In order to find Iranian lifestyle trails, we may discuss a process that "consumption" and the policy to face this concept are at the center of this process. The concept of consumption in Iran is not so positive meaning, and importantly, the concept of "consumerism" is more common than the consumption in Iran. On the one hand, consumerism expresses the concept of "lavish" and on the other hand, it represents the culture of Western societies. Although the wave of anti-consumerism was intensified after the revolution, it rooted in prerevolutionary intellectual traditions (Kazemi, 2016)."Returning to the principle" discourse that social thinkers and authors such as Jalal Al-e Ahmad and Ali Shariati represent it, is an attempt to adapt universal Western culture with the native culture of Iran (Mirsepassi, 2014) that the fight against Westernization led to criticism of the new middle class lifestyles and their consumption around new demands such as freedom and democracy as identified. But middle class who were called Westernized by Jalal Al-e Ahmad, is the class which attends to Western symbols and it is seeking comfort. This timid class attends its appearance and beauty; on the other hand of the continuum, religious ideology, ascetic religious-revolutionary strategy is that counters consumerism and condemns it (Kazemi, 2016). This approach represents a revolutionary Islamist lifestyle which is influenced by Islam's emphasis on Islamic values to the rejection of Western consumerism (Azadramaki, Shalchi, 19 ...). And this is where consumerism has spread; people with new ways of living, thinking and action and accustomed standard of moral and aesthetic judgments had changed (Kazemi, 2016). Figure 1 shows the continuum of Iranian lifestyle.

So, different and sometimes contradictory currents make the community as cultural arena of struggle and conflict. Global cultural changes in interact with social developments in Iran, Iranians diverse lifestyles and the second is changeable and unstable. Iranian society is the arena of different lifestyles competition to impose the legitimate definition and standard of life. Two post-modern lifestyles 


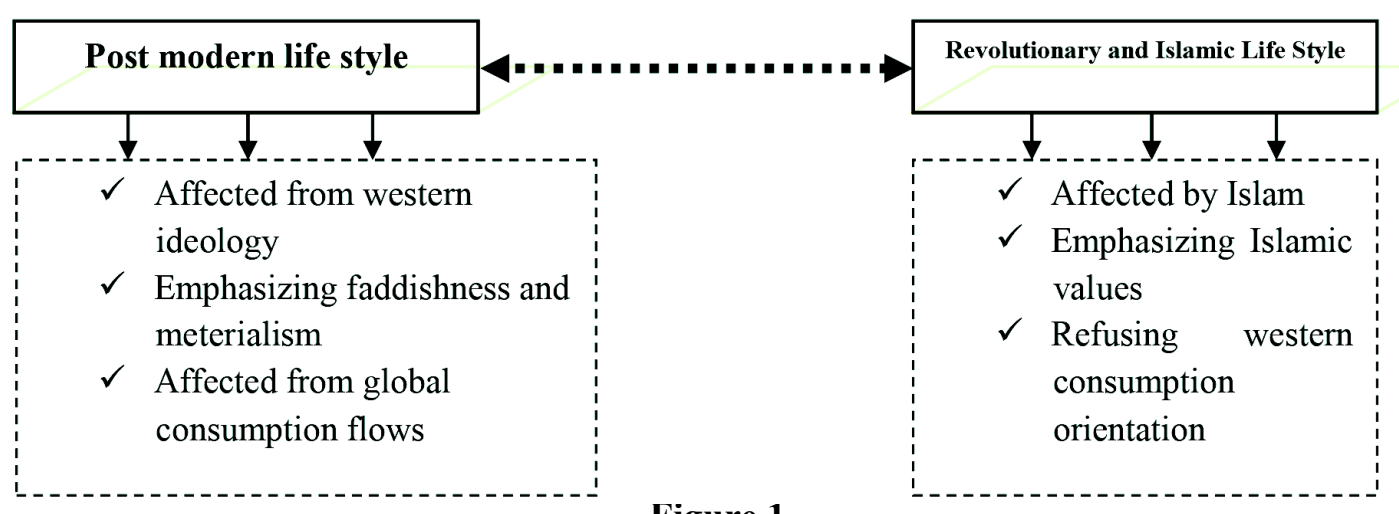

Figure 1.

Appendix to the Iranian Lifestyles

and conservative revolutionary struggle and competition are the both ends of the continuum. These lifestyles are against each other. In this, they have both identity and the identity of the legitimacy of the resistance identity is at the same time. Conservative national identity such as identity, legitimizing and at the transnational level acts as resistance identity. On the contrary, the legitimacy of the global identity of postmodern identity against the official culture acts as a resistance identity (Zadarmky, Shalchi, 19).

\section{Typo-morphology}

Typo-morphology is a combination of two words morphology and typology. Typology deals with the approach to classify types according to their function in their places. Landscape design of buildings and urban projects can be categorized according to common objectives or structured form. Classification and application of building types are designed based on specific issues of interest to designers. It involves a set of values (Lang, 1987). Rappaport believe that a concept deals with the type, class or group of people or groups of objects indicating certain characteristics in common features and these features will distinguish them from other groups of objects. He believes that typology attempts to put a set of complex objects in a regular series to achieve greater publicity for recognizing and planning (Rapoport, 1990). Radeberg believes typology is utilised to describe urban structure in terms of various features, analytical instruments and the link between environmental data and economic- social species which is defined as a planning tool by providing in-depth understanding urban types ( Radberg, 1996).

On the other hand, scholars have explored the inner structure of cities from various fields of urban planning through urban morphology studies and also the main skeletal structure. Morphology, as defined by Carmona, is studying forms and types of human habitats which provides a better understanding of development and changing processes of local patterns for urban designers (Carmona et all, 2012). Madanipour (1996) defines morphology as systematic form, shape, map, structure and functions of physical aspects of cities and the origin of the tissue over times. Moudon also believes that the morphology concentrates on the tangible results of social forces and the economy, and tends to study the consequences of ideas and goals when they form on the ground and shape our cities (Moudon, 1994) as the definitions coming out of the various elements. Table 1 shows morphological elements of the city in view of morphologists.

Typo-morphology divides the urban tissue into homogeneous and integrated areas through the selection of appropriate elements out of tissue referring to criteria for analysis. Each of these areas that have been based on elements from other distinct areas called morphological species. More than having focus on form and architectural style of buildings, Typomorphology concentrates on the relationship between buildings and areas of focus include (Daneshpour, Moradi, 2012). Kropf knows the three main components of Typo-morphology as follows: Position of the piece, the design of 

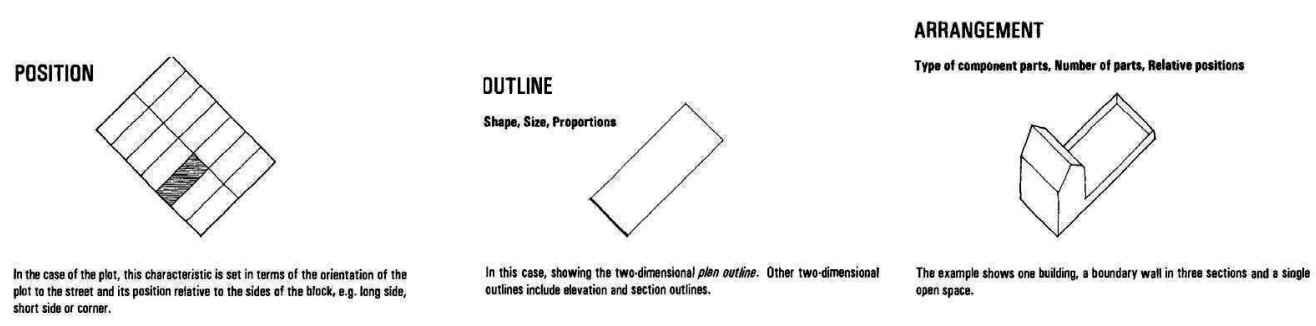

Figure 2.

Characteristics used in describing elements of urban form, taking the plot as an example
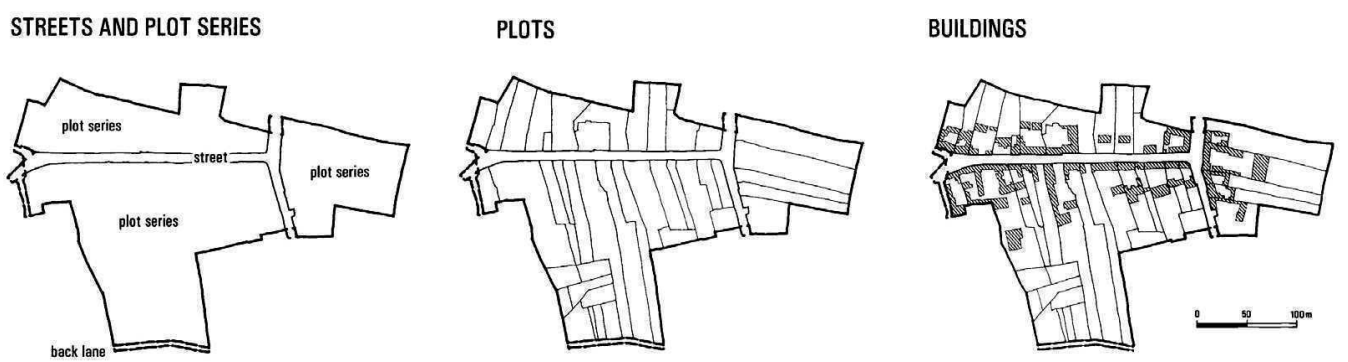

Figure 3.

Urban tissue shown at increasing levels of resolution.

The example is La Petite Rue from the village of Mery-la-Bataille, France

the piece, the arrangement of components in the piece (Kropf, 1998). He combines German and Italian schools of morphology and presents the theory of urban tissue. According to the theory, urban tissue is the physical synthesis of all components. It is an organic whole that distinguishes clearly visible on the surface. Higher resolution results in showing more details. At the most general level, the tissue can be described as the organization of streets and blocks. Describing a structure with all its details means description of its components and organization; including seating, layout and internal organization.

-Position: represents the relative position of element than other elements

-Outline: description of the external borders in terms of shape, size and proportion

-Character: Organization of components, the number of components and their relative position

In this theory, typology is based on outline plan, structural components and internal organization and districts which are distinct in physical areas, are also distinct in terms pf historical aspects (Mirmoghtadaee, 2006). Figure 2 shows characteristics used to describe the elements of an urban form. This example shows the characteristics of a parcel. Figure 3 also shows the urban tissue in different resolution levels.

Moudon offers a framework for Typomorphology studies. Accordingly, Typomorphology studies are classified in three categories:

-Volumetric properties of artificial structures according to related to open spaces used for defining artificial landscape

-Land and its division as a link between the building scale and the scale of the city

-Study of the urban landscape as a kind of evolution on the assumption that the urban landscape defines the time (Moudon, 1994).

So, Typo-morphology assessment is the essential tool used in evaluating urban areas which shows different stages of growth and progressive development of the city, the relationship between buildings and types of parts, building blocks and streets (Daneshpour, Moradi, 2012).

Developments of residential tissues in Iran

Up to the end of the Qajar period (1299 AH), Iranian cities developed with a consistent growth and spread pattern. During this period, the market 
is still the main door and the backbone of the city and neighborhoods survive as semi-independent location in the heart of the city. These ancient areas lost their old connection with similar villages, despite the fact that they still kept their societies (Habibi, 2003). By the end of the Qajar and early Pahlavi, the changes intensified. This was the main indicator of state-building era (Abrahamian, 2016). Accordingly authoritarian modernization got priority by the Pahlavi government in its modernization agenda but public socialization and acculturation failed to accompany society. And "modernity in society" changed to "modernization" which fell under the authoritarian of government (Farasatkhah, 2016). The Pahlavi government showed a curtailment of history, society and the city definitions which were not only contradictory and mutual; but contradictory to suggest: the contradiction between the concepts of culture and Western culture, the contradiction between the continuation of historical discontinuity historical conflict between traditions old and new ways of living environment (Habibi, 2003).

During this period, the city became a place for the exposure of all the protests and sociocultural differences and physical-space which extends with no criterion in all directions. This process was implemented through unplanned land occupation as the main element of transactions and the type of architecture was strongly related to principles of modern architecture and in most cases, it was against biological methods and even climatic terms.

The city of this place is the number of blocks of a city defined by streets around without any lifting of physical space-gathered together (Habibi, 2003). This approach also continued during the era of the second Pahlavi and it was developed by the strength of the government and the formation of a new middle class, style of residence is changed. Thus, in the late 40 's and early 50's, number of apartments increased. Increase of urban population, deficiency and expensiveness of land in urban areas, high costs of serving large-scale city, low price of apartment in comparison with villa housing (Nasri, 1995) on the one hand and the simultaneous introduction of latest developments in the apartments with family and the loosening of family ties and relations and fitness of apartment with modern type of family are the main reasons for attraction to the apartment (Nadimi, Olia, 2014).

The transition from Pahlavi Era with the dominant pattern of public modernization in the period after the revolution was the dominant pattern Islamization of state (Farasatkhah, 2016). Upon the occurrence of the Islamic Revolution, internal migration to major cities rose (Kamrava, 2012). The first five years of the revolution, the country, especially in big cities faced with a deficient municipal administration; so, in an ideal atmosphere for the realization of the principles of the constitution on the provision of housing, various organizations including Housing Foundation began the separation of land for transferring them to applicants (ibid. 73), controls and restrictions on urban areas were eliminated.

Housing developed in suburban areas; tenants and nomadic migrants started settling in suburban regions due to suffering from heavy rents. Much of housing acts were for personal use (Ahari quoted from Ghanbari, Zaheri, 2010). Urban structure in the first decade after the revolution was experiencing horizontal expansion. In this era of war and reduced oil revenues and increased demand for housing, land preparation plans have started. But, these plans have failed to achieve the patterns derived from the values and trends in society and schools of thought often imported models and comprehensive plans of cities and settlements before the revolution (Kamrava, 2012).

Developments of building tissue after the Islamic Revolution illustrated the crisis of legitimacy in the city and the consequent crisis of authority and the financial crisis in the cities of Iran on the one hand and the rejection of Western models in all political and social aspects and consequently in Urbanization patterns on the other hand, have not offered an alternative model; and we were faced with a void in urban development patterns. In this era, serious conflicts and contradictions emerged between the values and ideals of Islam and forms of urban systems. This contradiction emerged in mass transfer and non-residential standards in towns and cities, often for unplanned developments and plans in developing urban plans based on the exploitative and speculative 
tendencies (Kamrava, 2012). Table 2 shows changes in the residential tissue in Mashhad.

Typo-morphology of residential areas in the city of Mashhad

According to studies, Typo-morphology of residential tissues in Mashhad was performed at the macro level and the middle level and in three types of tissues include old, middle and modern, as developed in the following tables:

A. Old Tissue (historical):

Table 3,4 show:

-Up to 1931, establishment of Hazrat square was the most important change in old tissue

-Since mid-30s, decaying procedure of tissue began slowly.

-In a 40 years period, from 50's, the following change was occurring in old tissue; considering the thoughts affected by modern age, green ring was made around the shrine and a major part of old tissue was destructed.

-After a 30-year-old, the old tissue experienced its most important shift period. From the 70s onwards, typo-morphology of tissue underwent significance changes in the three large-, medium- and micro- scales. Without evidence of the past with it. In largescale, geometry and logic of tissue were undergoing changes. In middle scale, the size become coarse-grained with aggregate of remaining fine grains causing previous periods and in micro-scale, tissue confront with increasing density and number of classes.

\section{B. Middle Tissue}

Table 5,6 show:

-Middle texture from the beginning of its formation (50's) has started its growth with the dominant geometric-chess pattern; until recently, typo-morphology of middle tissue had been having no change in middle and largescale; but at the micro-scale as of 60's onwards (after a period of 40 years), we have faced with increasing density and increasing number of floors and using of apartment patterns.

C. The new tissue

Table 7,8 show:

-The new tissue started its growth in chess geometry style since the late 70's. In small scale, it follows four patterns of villas, apartments, residential complexes and highrise building. The trend in new tissue begins less than two decades later. These changes were in two groups: maintaining typo-morphology of the lot along with increasing in dense and number of floors along with changing pattern from villa to apartment and on the other hand, integration of parts along with increasing in dense and using high-rise pattern.

\section{Conclusion}

It sounds that the dialectic between construction and destruction, according to the theory of short-term society has changed historical periods of Iran to short-term periods. Studies show that in modern times, and after Iranian confrontation with the West, construction and destruction periods became shorter. Changes in Iranian society over the last century including for constitutional revolution, social-political events of Pahlavi era, the Islamic Revolution confirms this. Another important difference between short time period of contemporary history and earlier period is changes are spreading along physical aspect of urban area. This means that each time the Iranians change their life style, topology of city reacts and in the wake of the devastation, the city is created again in a new form. So the old society creates old city in the heart of old town, old house arises. Thereby, topology of a city shows cycle of destruction and reconstruction and it is permanent. Figure 4 shows short-term changes in lifestyle and residential Typo-morphology of residential tissues of Iran.

Review of the Figure 4 shows that before the era of being affected from the West, changes in lifestyle and residential tissue shows the continuation of past patterns based on the gradual transformation. But after this period and especially the first Pahlavi era to the next, new ways of living can be raised in opposition to the ancient traditions, relying on authoritarian modernization.

This new approach is based on the rejection of past values; and demands its new form. That is why the city undergoes changes and destructs 

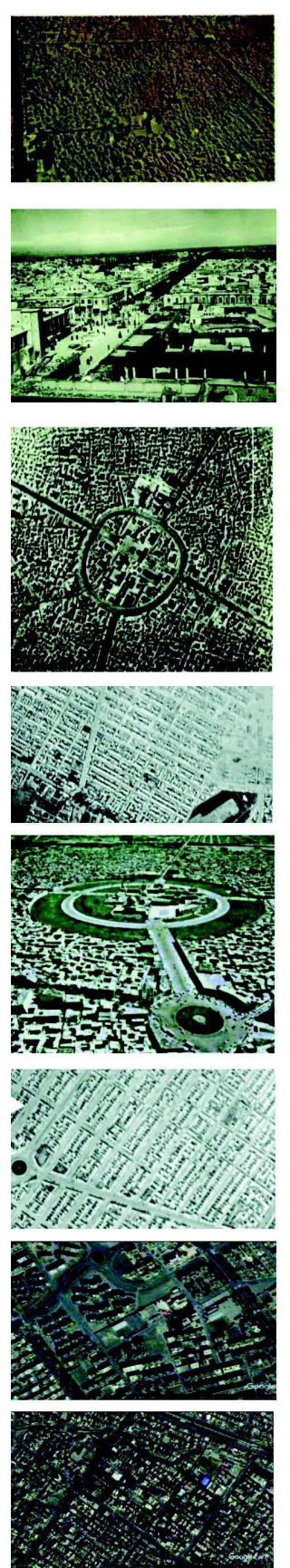

Continuation of past patterns based on the change and evolution

$\checkmark \quad$ market as the core of the city and the neighborhood as a main ingredient urban space

neighborhood place for exposing Ethnic, Racial and Ethnic anpearances

\section{$\longleftarrow$}

$\checkmark \quad$ The formation of the streets in the new concep

$\checkmark$ formation of new communities in relation to the street

$\checkmark$ neighborhood as a place for social distinctions

$\checkmark$ housing pattern: Traditional

tissue: Organic

$\checkmark$ The destruction of the old city walls disruption of the spatial organization of the city new street lining

$\checkmark \quad$ the beginning of the isolation of old tissue

$\checkmark$ Suburban development through indiscriminate occupation of land

$\checkmark \quad$ Defining new urban areas based on the principles of new urbanism and architecture

$\checkmark$ development of housing based on income levels

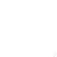

Spatial physical manifestation of social and cultural differences

$\checkmark$ Development of the city as geometric form

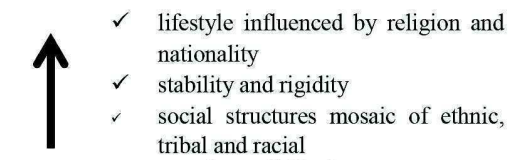

\section{$175 \mathrm{AH} \longrightarrow$ rise of Qajar}

$\checkmark$ Start of the age of influences of Europe

$\checkmark$ formation of the middle class

$\checkmark$ Constitutional Revolution, an attempt to embrace modernity

\section{$1925 \longrightarrow$ rise of Pahlavi}

Authoritarian modernization

$\checkmark$ Upgrading of authoritarian government

$\checkmark$ rejection of traditions, institutions and values of Iran

$\checkmark$ Age duality: the duality between old traditions and new ways of life

$\checkmark$ strengthen urbanization

$\checkmark$ exposure of cultural differences and social protests

\section{$1941 \longrightarrow$ rise of 2nd Pahlavi}

$\checkmark \quad$ The government basis

$\checkmark$ strengthen the middle class by bringing in government offices

$\checkmark$ loosening family ties and relations

\section{$-\quad 1961$}

$\checkmark$ Spread of apartment settlement

$\checkmark$ forming middle tissue with the dominant pattern of villa housing

aging of old tissue and displacement of population to tissue

$\checkmark$ development of consumption orientation

$\checkmark$ forming conversation for getting back to interaction of culture with modernization

$\checkmark \quad$ loss of social capital

$\checkmark$ forming centralized family

$\checkmark \quad$ starting displacement of intercity population

\section{$\checkmark$ Horizontal expansion of cities}

$\checkmark$ separation and transfer of land

$\checkmark$ Preparation plans affected by Western models

$\checkmark$ formation of new tissue with the dominan pattern of housing

$\checkmark$ repair of middle tissue as vertical expansion

encourage mass construction with the pattern of residential complexes

$\checkmark$ Construction of housing for lowincome classes

Renovation!!!! new tissues as apartment and tower patterns

\section{$1978 \longrightarrow$ Islamic Revolution}

$\checkmark$ Public Islamization

$\checkmark$ formation ascetic revolutionary ideology

$\checkmark$ rejection of Western consumerism 1991 the importance of poor people

$\checkmark$ development of capitalism

$\checkmark$ Strengthen middle class based on consumption

promote social justice discourse against the dominant discourse of the middle class

the importance of low-income classes

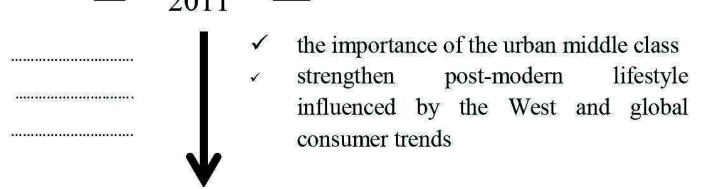

Figure 4.

Short terms of change in lifestyle and typo-morphology of residential tissues of Iran.

old tissues and makes its new spatial structure.

From this time onwards, the city get placed in the vicious cycle of destruction-construction. In the second Pahlavi era, the lifestyle of the middle class does not tolerate old tissue and searches for life in new tissues; new tissues are the result of suburban life development and form in grid and mostly in villa type. Since the second Pahlavi era, apartments' ownership act was approved and changed the Iranian lifestyle which led in changes in lifestyle and development of apartment lifestyle.

On the other hand, developing pre urban region resulted in the isolation of old tissues 
as well. The Islamic Revolution led to deny ideology and all the other trappings of the West. Immigration of low class people to cities forced the state to supply housing and assign lands to them in suburban areas and resulted in horizontal expansion of cities. But, after the war and with the government's economic policies, once again the importance of the urban middle class appeared. Middle tissues changed their pattern from villa to apartments and underwent horizontal development and underwent mass construction policies in external developments.

In the third decade after the revolution, the discourse of social justice formed for supporting the low income people, and in the sphere of housing, started the construction of Mehr social housing out of the cities; although at the same time, and particularly in the fourth decade after the revolution, it seems that middle class may not be ignored anymore. In the same time, by strengthening of postmodern life style affected from the West and global movements of consumption, housing pattern of new tissue has changed its pattern from villa to apartments and towers.

Therefore, cities undergo destructions and reconstruction in short-terms of 20-30 years and change and transience originate without any sense of time in city.

\section{References}

Abazari, Y., \& Chavoshian, H. (2002). From Social Class to Lifestyle, Social Sciences Journal, No. 20, Tehran. (In Persian).

Abrahamian, E. (2016). Modern History of Iran, translated by Mohammad Ibrahim Fattahi, Ney Press, Thirteenth Edition, Tehran. (In Persian).

Allain, Remy,(2004), Morphologie urbaine Géographie, aménagement et architecture de la ville, Armand Colin.

Azad armackie, Taghi, \& Shalchi, V. (...). Two Iranian World: the mosque and coffee shops, Quarterly Journal of Iranian Society of Cultural Studies and Communication, Tehran. (In Persian).

Benedikter, Roland, M. Juergensmeyer, $\mathrm{H}$. Anheier (2011), Lifestyles, The SAGE Encyclopedia of Global Studies.
Carmona, Matthew, Tim Heath, Taner Oc, Steve Tiesdell,(2012), Public Places Urban Spaces, Routledge.

Catanese, Anthony, James C. Snyder, (1979), Introduction to urban planning, McGrawHill, New York.

Conzen, M.R.G, (1969), Alnwick Northumberland: A Study in Town Plan Analysis, 2nd ed, London: Institute of British Geographers.

Conzen, M.R.G, (1960), Alnwick: A Study in Town Plan Analysis, Transactions, London: Institute of British Geographers.

Daneshpour, S. \& Moradi, S. (2012). codifying the typomorphology method and its application in urban design, architecture and urbanism Journal, No. 9, Tehran. (In Persian).

Farasatkhah, M. (2016). The Iranians; historical and social background study of Iranian mood, Ney Press, 10th edition, the second edition, Tehran. (In Persian).

Ghanbari, A., Zaheri, M., (2010), assessment of macro policies of housing in programs before and after the Islamic revolution, Journal of Housing and Rural Environment, No. 132, Tehran. (In Persian).

Habibi, S. (2003). From the street to the city, Institute of Tehran University Press, 4th Edition, Tehran. (In Persian).

Hajian, E. (2007). Patterns of Iranian lifestyles, Institute of Strategic Research Center, Tehran. (In Persian).

Kamrava, M.A. (2012). Iranian Contemporary History, Tehran University Press, 4th Edition, Tehran. (In Persian).

Katozian, M. (2014). Iran of the short-term Society, translated by Abdullah Kothari, Ney Press, 6th Edition, Tehran. (In Persian).

Kazemi, A. (2016). Daily affair in postrevolutionary society, Javid Culture Publications, Tehran. (In Persian).

Kropf, K,(1998), Typological Zonning IN petruccioli, Attilio(1998)Rethinking XIXTH Century cities, Proceedings of the international symposium sponsored by the Aga Khan program for Islamic Architecture at Harvard Univesity and the Massachusetts Institute of Technology.

Kropf, Karl (1996), Urban Tissue and the Character of Towns, Urban Design 
International, Vol.1, No.3.

Lang, Jon, (1987), Creating Architectural Theory: The Role of the Behavioral Sciences in Environmental Design, Van Nostrand Reinhold Company.

Madanipour, Ali,(1996), Design of urban space: an inquiry into a socio-spatial process, Wiley.

Maller,A. (1998), Emerging Urban Form Types in a City of the American Middle West, journal of Urban Design, 3:2, 137-150.

Merriam-Webster Dictionary

Mirmoghtadaee, Mehta (2006), Proposing a method for analyzing the character of the city, Environment Science Magazine, Number 39, Tehran. (In Persian).

Mirsepassi, Ali. (2014), Reviewing Iranian modernity, Translator: Jalal Tavakkolian, 3rd Press, Tehran. (In Persian).

Moudon, A V.(2000), Proof of goodness: a substantive basis for new urbanism. :38-43

Moudan, A V.(1994), Getting to know the built landscape: typomorphology, in: K.A.Frank \& L.H.Schneeckloth(Eds), Ordering Space Types in Architecture and Design(New York,VNR):289-311

Nadimi, H, Olia, M. R., (2014), the porch, the ten articles in architecture, Academy of Arts Press, Tehran. (In Persian).
Nasri, M., (1975), vertical housing, horizontal culture, set of papers for the Seminar of Housing Development Policies in Iran, edited by Mehdi Talib Elm, published by the Ministry of Housing and Urban Development, Tehran. (In Persian).

Oxford Dictionary

Piran, P. (2005). the theory of strategy and policy of territorial community, Andisheh Quarterly Journal of Iranshahr, 2nd Edition, No. 6, Tehran. (In Persian).

Pourdeihimi, S. (2011). Culture and Housing, Journal of Housing and Rural Environment, No. 134, Tehran. (In Persian).

Rådberg J., (1996), Towards a Theory of Sustainability and Urban Quality: A New Method for Typological Urban Classification, in Gray M., (ed.), Evolving Environmental Ideals: Changing Ways of Life, Values and Design Practice, Book of Proceedings for the 14th Conference of the International Association for People-Environment Studies, Stockholm, pp.384-392.

Rapoport Amos, (1990), Vernacular Architecture, in Turan M., (eds.); Current Challenges in the Environmental Social Sciences, Avebury, Aldershot, England.

Rapoport Amos, (1969), House Form and Culture, Prentice-Hall.

\section{Appendix}

Table 1: morphological elements of the city in view of morphologists

\begin{tabular}{|l|cl|}
\hline \multicolumn{1}{|c|}{ Theorist } & \multicolumn{3}{|c|}{ Urban Typo-morphology Elements } \\
\hline \multirow{3}{*}{ Conzen, 1960,1969 } & $\checkmark$ & land use \\
& $\checkmark$ & building structure \\
& $\checkmark$ & Segmentation pattern \\
& $\checkmark$ & street pattern \\
\hline \multirow{3}{*}{ Remy Allain, 2004 } & $\checkmark$ & elements: the Conzen elements \\
& $\checkmark$ & structures: their own way of organizing the elements: tissue \\
& $\checkmark$ & logic: ideology or decision which helps to create any structure \\
\hline \multirow{3}{*}{ Maller, 1998 } & $\checkmark$ & linear elements: pass ways and borders \\
& $\checkmark$ & surrounded elements: by square and streets \\
& $\checkmark$ & bulky and macro elements: blocks and parks \\
& $\checkmark$ & marginal elements: the coast, railways \\
\hline \multirow{3}{*}{ Kropf,1998 } & $\checkmark$ & urban tissue: the most important concept in Typo-morphology \\
& $\checkmark$ & elements: the streets and block / plates / buildings / rooms and spaces \\
& & / walls and ceilings (building parts) / materials \\
& $\checkmark$ & Different elements are connected in a hierarchy. \\
\hline
\end{tabular}


Table 2: Developments in residential tissue in Mashhad

\begin{tabular}{|c|c|}
\hline Historical term & Changes in residential tissues \\
\hline Qajar era & $\begin{array}{ll}\checkmark & \text { main elements: the shrine, upstream and downstream streets, Arg, neighborhoods, } \\
& \text { markets, fort } \\
\checkmark & \text { main areas: upstream and downstream streets, Mirage, Noghan, Eidgah, Chaharbagh } \\
\checkmark & \text { build communities based on housing patterns and ethnic and traditional affiliations } \\
\checkmark & \text { tissue type: Organic }\end{array}$ \\
\hline $\begin{array}{l}1931 \\
\text { 1st Pahlavi }\end{array}$ & $\begin{array}{l}\checkmark \quad \text { Mess of urban space organization and the structure of old neighborhoods of } \\
\text { the city with the construction of Hazrat square and Tehran and Tabarsi streets } \\
\text { destruction of the fort of the city } \\
\checkmark \quad \text { Changing farms and gardens to residential areas } \\
\checkmark \quad \text { Changing housing pattern and social tissue based on income levels and reducing ethnic relations } \\
\checkmark \quad \text { construction of the first four storey building }\end{array}$ \\
\hline $\begin{array}{l}1941 \\
\text { 1st Pahlavi }\end{array}$ & $\begin{array}{l}\text { Mess of urban space organization and the structure of old neighborhoods after the } \\
\text { establishment of Shohada Square, Daneshgah and Arg streets } \\
\text { establishing administrative centers and modern resort on the edge of Shohada Square and } \\
\text { Daneshgah and Arg streets } \\
\text { the creation of new urban functions and activities in accordance with changes in lifestyle, } \\
\text { such as theaters, cinemas, solarium, factories, universities, railway, airport } \\
\checkmark \quad \text { Development began in the West and Southwest inspired by Western models and in chess form }\end{array}$ \\
\hline $\begin{array}{l}1954 \\
\text { 2nd Pahlavi }\end{array}$ & $\begin{array}{ll}\checkmark & \text { continuing development of the city to West and Southwest inspired from Western models } \\
\checkmark & \text { and chess form } \\
\checkmark & \text { Destruction of the villages around the city } \\
& \text { restructuring of extended families to core ones and moving from central and historical } \\
\checkmark & \text { tissue to the new tissue } \\
\checkmark & \text { replacement of immigrants in aged tissues and starting the aging process in historical tissue } \\
\checkmark & \text { formation of new residential tissues in one or two floors affected by climate }\end{array}$ \\
\hline $\begin{array}{l}\text { After the Islamic } \\
\text { Revolution }\end{array}$ & $\begin{array}{ll}\checkmark & \text { continuing development of the city to West and Southwest inspired from Western models } \\
\checkmark & \text { and chess form } \\
\checkmark & \text { Destruction of the villages around the city } \\
\checkmark & \text { Starting land preparation plans in early Islamic Revolution } \\
\checkmark & \text { growth of marginalization and informal suburban settlements } \\
\checkmark & \text { renovating historical tissue with new patterns } \\
\text { Avoiding horizontal expansion of the city in the first decade after the revolution and } \\
\text { beginning middle tissue maintenance plans for vertical expansion }\end{array}$ \\
\hline
\end{tabular}

Table 3: large-scale typo-morphology classification for old tissue

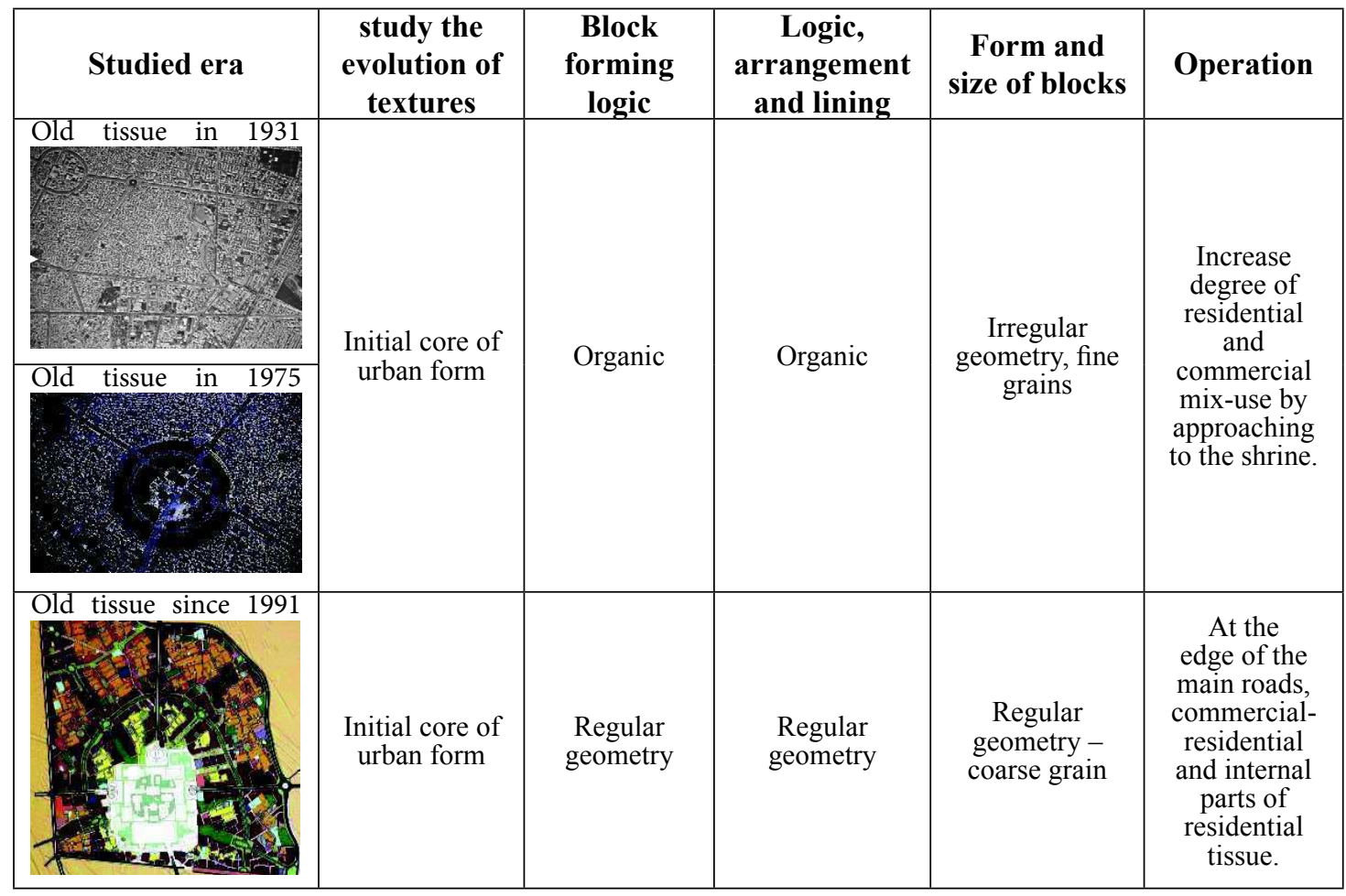


Table 4: middle-scale typo-morphology classification for old tissue

\begin{tabular}{|c|c|c|c|c|}
\hline Studied era & $\begin{array}{c}\text { Topology } \\
\text { pattern }\end{array}$ & $\begin{array}{l}\text { Form and } \\
\text { size of parts }\end{array}$ & Operation & $\begin{array}{c}\text { Arrangement } \\
\text { of parts of } \\
\text { building }\end{array}$ \\
\hline \multirow{4}{*}{ 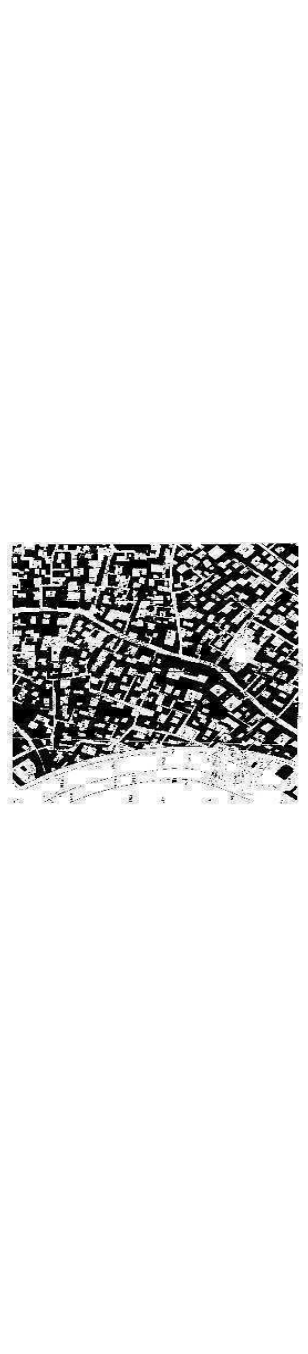 } & & $\begin{array}{l}\text { Parts have non } \\
\text { geometrical } \\
\text { forms }\end{array}$ & $\begin{array}{l}\text { In internal parts of } \\
\text { tissue: residential } \\
\text { building on the edge } \\
\text { of the main roads, } \\
\text { increase the degree of } \\
\text { mixing commercial } \\
\text { with residential land } \\
\text { uses by approximating } \\
\text { to shrine. }\end{array}$ & $\begin{array}{l}\text { Mass covers a } \\
\text { large part of the } \\
\text { lot. }\end{array}$ \\
\hline & & $\begin{array}{l}\text { Parts have non } \\
\text { geometrical } \\
\text { forms } \\
\text { Direction of } \\
\text { parts is effective } \\
\text { in classification }\end{array}$ & $\begin{array}{l}\text { In internal parts of } \\
\text { tissue: residential } \\
\text { building on the edge } \\
\text { of the main roads, } \\
\text { increase the degree of } \\
\text { mixing commercial } \\
\text { with residential land } \\
\text { uses by approximating } \\
\text { to shrine. }\end{array}$ & $\begin{array}{l}\text { It has separated } \\
\text { part from the } \\
\text { main building }\end{array}$ \\
\hline & & $\begin{array}{l}\text { Parts have non } \\
\text { geometrical } \\
\text { forms } \\
\text { Direction of } \\
\text { parts is effective } \\
\text { in classification }\end{array}$ & $\begin{array}{l}\text { In internal parts of } \\
\text { tissue: residential } \\
\text { building on the edge } \\
\text { of the main roads, } \\
\text { increase the degree of } \\
\text { mixing commercial } \\
\text { with residential land } \\
\text { uses by approximating } \\
\text { to shrine. }\end{array}$ & $\begin{array}{l}\text { It does not have } \\
\text { separated part } \\
\text { from the main } \\
\text { building }\end{array}$ \\
\hline & & $\begin{array}{l}\text { Parts have non } \\
\text { geometrical } \\
\text { forms } \\
\text { Direction of } \\
\text { parts is effective } \\
\text { in classification }\end{array}$ & $\begin{array}{l}\text { In section within the } \\
\text { tissue of: building on } \\
\text { the edge of the main } \\
\text { roads of the mixing } \\
\text { commercial with } \\
\text { residential proximity } \\
\text { to the shrine increases. }\end{array}$ & $\begin{array}{l}\text { It does not have } \\
\text { separated part } \\
\text { from the main } \\
\text { building }\end{array}$ \\
\hline Since 1990s & & $\begin{array}{l}\text { Parts have non } \\
\text { geometrical } \\
\text { forms } \\
\text { Parts are } \\
\text { affected by } \\
\text { street form }\end{array}$ & $\begin{array}{l}\text { At the edge of } \\
\text { the main roads, } \\
\text { commercial-residential } \\
\text { and internal parts } \\
\text { of residential - } \\
\text { commercial tissue. }\end{array}$ & $\begin{array}{l}\text { setting of mass in } \\
\text { lot based on lot } \\
\text { form and as street } \\
\text { side }\end{array}$ \\
\hline
\end{tabular}


Table 5: Large-scale typo-morphology classification for middle tissue

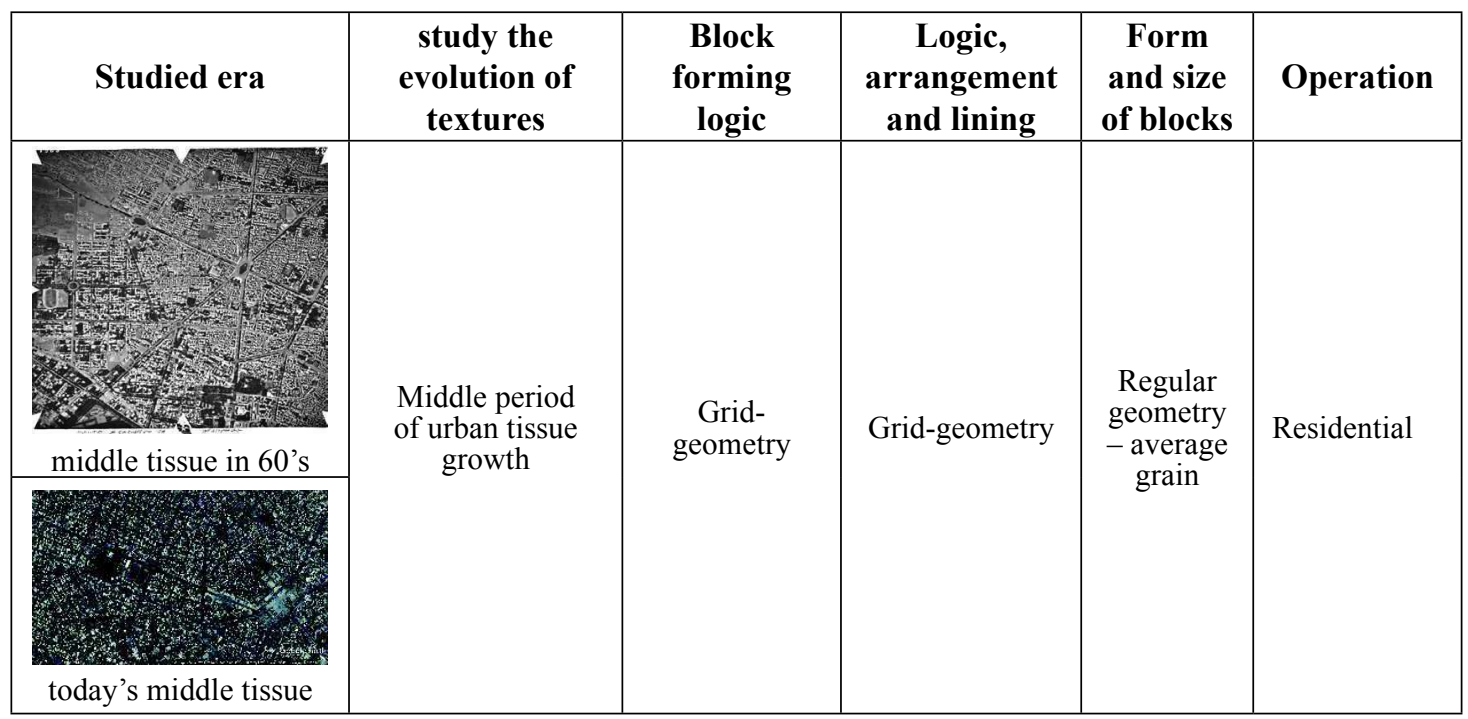

Table 6: Middle -scale typo-morphology classification for middle tissue

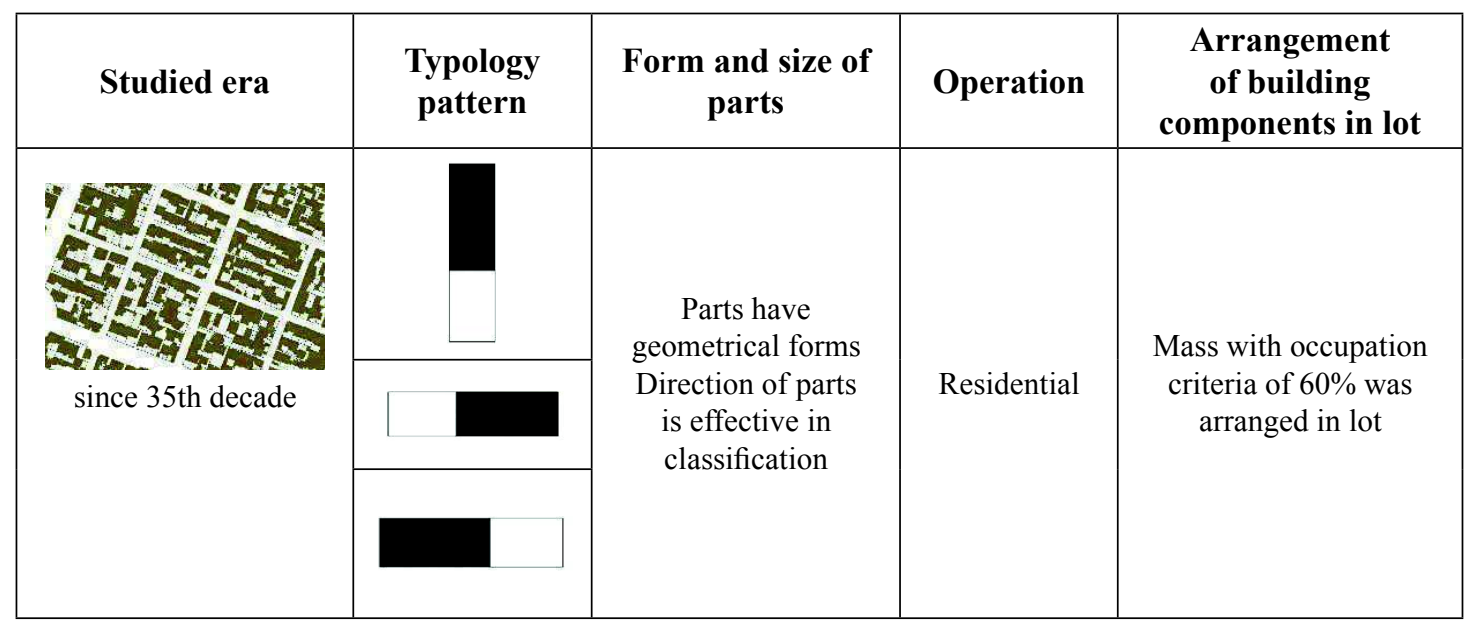

Table 7: Large-scale typo-morphology classification for new tissue

\begin{tabular}{|c|c|c|c|c|l|}
\hline Studied era & $\begin{array}{c}\text { study the } \\
\text { evolution of } \\
\text { textures }\end{array}$ & $\begin{array}{c}\text { Block } \\
\text { forming } \\
\text { logic }\end{array}$ & $\begin{array}{c}\text { Logic, } \\
\text { arrangement } \\
\text { and lining }\end{array}$ & $\begin{array}{c}\text { Form and } \\
\text { size of blocks }\end{array}$ & Operation \\
\hline & $\begin{array}{c}\text { Last period } \\
\text { of tissue } \\
\text { growth }\end{array}$ & $\begin{array}{c}\text { Grid- } \\
\text { geometry }\end{array}$ & $\begin{array}{c}\text { Grid- } \\
\text { geometry }\end{array}$ & $\begin{array}{c}\text { Regular } \\
\text { geometry - } \\
\text { average grain }\end{array}$ & Residential \\
\hline
\end{tabular}


Table 8: Middle-scale typo-morphology classification for new tissue

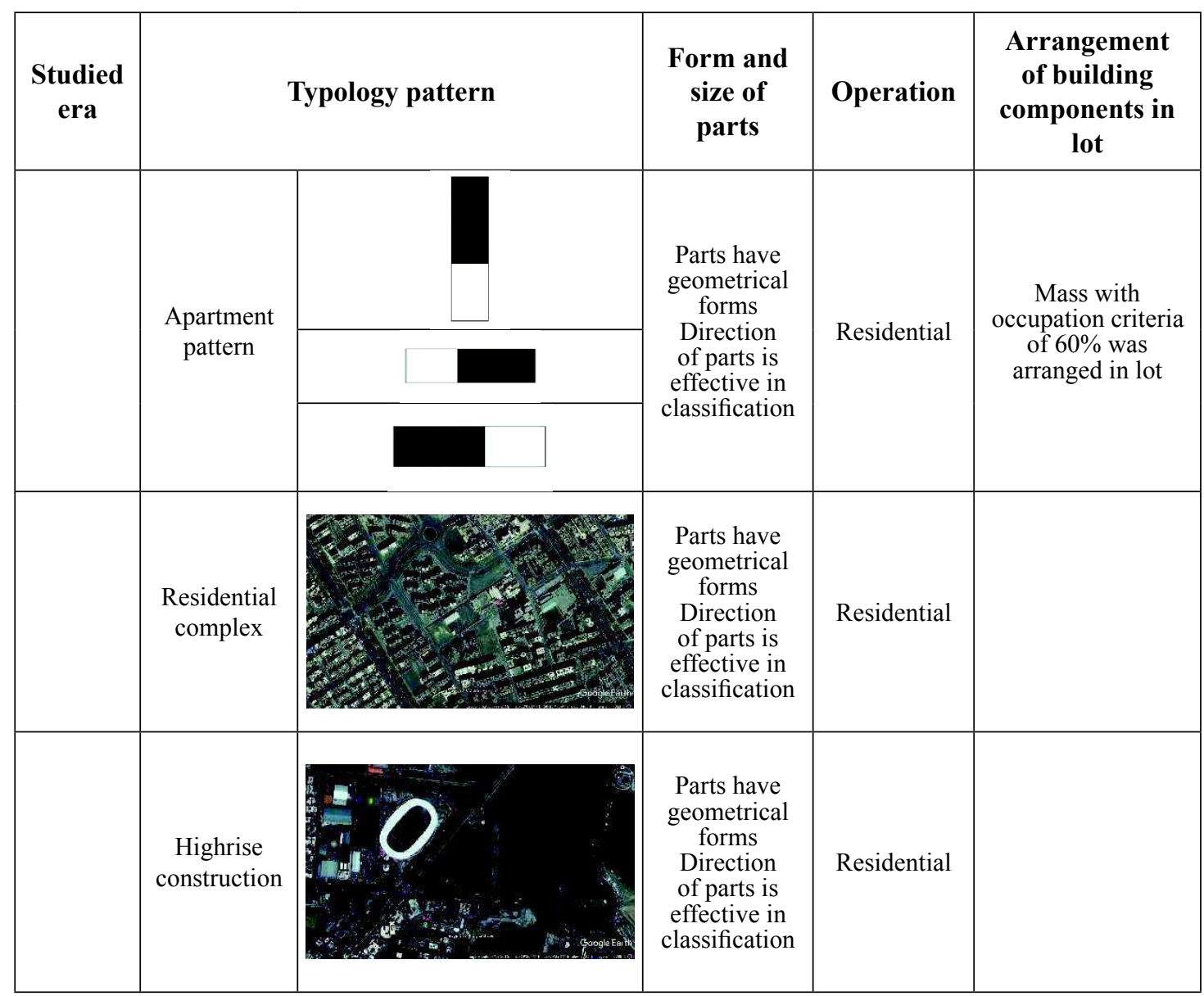

